\title{
Trophic condition of the volcanic Lake Nemi (Central Italy): environmental factors and planktonic communities in a changing environment
}

\author{
Fiorenza G. MARGARITORA*, Bruno FUMANTI ${ }^{1)}$, Silvia ALFINITO ${ }^{1)}$, Gianni TARTARI ${ }^{2}$, Daria VAGAGGINI, \\ Marco SEMINARA, Paolo CAVACINI ${ }^{1)}$, Elisa VUILLERMOZ ${ }^{2)}$ and Marilena ROSATI
}

Department of Animal and Human Biology - University "La Sapienza", Roma, Italy

${ }^{1)}$ Department of Plant Biology - University "La Sapienza ", Roma, Italy

${ }^{2)}$ CNR Istituto di Ricerca Sulle Acque, Brugherio, Monza.

*e-mail corresponding author: fiorenza.margaritora@uniroma1.it

\begin{abstract}
Lake Nemi is an interesting case of anthropogenic overexploitation which has caused its progressive environmental deterioration in the past decades. On this lake historical data about the trophic situation are available from 1975 to 1984. The research performed in 2002-03, about ten years after the diversion of urban waste waters, concerned a biological investigation on the phyto- and zooplanktonic communities, integrated with a physico-chemical analysis. The aims of our study are to evaluate the current water quality of the lake and compare it with the water quality observed in 1982-1983, when all biotic and abiotic components indicated a heavily compromised hypereutrophic condition. The water quality data and the comparison with a previous study point out that the biological aspects have partially changed (increased number of Cyanobacteria and phytoplanktonic taxa, particularly Clorophyta and Dinophyta; zooplankton composition changed at a species level, with the appearance of taxa associated to light trophic conditions), and the physico-chemical conditions significantly improved. The mean transparency, dissolved oxygen, nutrients and chlorophyll-a concentrations have all improved. Mean annual temperature at different depths increased, probably due to differences in climatic period and the lowering of the lake surface level (from 32.5 to $27.5 \mathrm{~m}$ in 1982 and 2002, respectively). Our results indicate a general improving trend in water quality is taking place since the diversion of waste water discharges. The present abiotic characteristics of the lake allow the phytoplankton to distribute itself in the whole epilimnion, and the zooplankton in the whole water column. A possible further improvement is hypothesized, and the constraints represented by excessive water level lowering and water temperature increasing are also discussed.
\end{abstract}

Key words: eutrophication, lake recovery, planktonic monitors

\section{INTRODUCTION}

Trophic changes in lake environments can be highlighted through the study of the structure and composition of the planktonic communities, and supported by the observation of the principal physical and chemical parameters of the waters. In fact, the variation of some environmental conditions following natural or anthropogenic stresses (e.g., increase of the nutrient concentrations, and modification of the oxygen depth distribution, etc.) often qualitatively and/or quantitatively alters these communities, that are made up of organisms with short life cycles that quickly respond to environmental change. It is possible to observe species substitutions and wide variations in density. Such modifications in the structure and dynamics of the planktonic communities allows us to draw useful pictures about the state of water quality in the lake environment and on its trophic trend, as has been done for a wide variety of lakes (Hessen et al. 1995; Manca \& Ruggiu 1998; Løvik \& Kjellberg 2003).

Lake Nemi is a warm monomictic lake in the Latium volcanic district (Central Italy), with a maximum depth of $27.5 \mathrm{~m}$ and a theoretical water renewal time of $15 \mathrm{y}$ (Tab. 1).
The onset of a strong trophic increase coincided with the artificial lake level lowering of about $20 \mathrm{~m}$ in order to recover the ancient ships of Caligola (Roman Emperor 37-41 AD) from the lake bottom. Such alteration is comfirmed both by the biological and physico-chemical observations (Volterra 1924; Volterra-D'Ancona 1938; D'Ancona \& Volterra-D'Ancona 1931, 1935, 1949; Maldura 1939; Pasquali 1939; Marchesoni 1940, 1949; D'Ancona 1942; Parise 1960) and the paleolimnological reconstruction (Masaferro et al. 1993; Chondrogianni et al. 1996; Manca et al. 1996).

Tab. 1. Main morphological features of Lake Nemi (from Margaritora et al. 2003).

\begin{tabular}{ll}
\hline Altitude & $316 \mathrm{~m}$ a.s.l. \\
Catchment area & $10.5 \mathrm{~km}^{2}$ \\
Lake surface area & $1.6 \mathrm{~km}^{2}$ \\
Maximum depth & $27.5 \mathrm{~m}$ \\
Mean depth & $16.5 \mathrm{~m}$ \\
Volume & $26.510^{6} \mathrm{~m}^{3}$ \\
Water renewal time & $15 \mathrm{y}$ \\
Thermal stratification & warm monomictic \\
\hline
\end{tabular}

As reported by Stella et al. (1978) the situation returned to the original status after about ten years and remained stable up to 1969 , as showed by sporadic 
observations by the Central Laboratory of Hydrobiology and afterwards by the Stabilimento Ittiogenico of Rome. The situation started to deteriorate from the beginning of the seventies due to the continuous and increasing inflow of both point and nonpoint pollution sources from the surroundings. Data collected in 1973-75 underlined a dominance of the Cyanobacteria in the phytoplankton, with blooms of Planktothrix rubescens (formerly Oscillatoria rubescens) for almost 8 months per year. As a result of this abnormal algal development and the anoxic hypolimnetic condition, fish kills occurred until the local extinction of coregonids.

The history of Lake Nemi, with its progressive heavy deterioration, has been well documented in an interdisciplinary work conducted in 1982-83, which included physico-chemical, phytoplanktonic, zooplanktonic and zoobenthic observations (Avena 1987).

In the last decade the lake seemed to undergo a recovery process (Margaritora et al. 2003). After a sewage treatment network was developed in the early nineties, discharges were diverted that had previously ended up in the lake basin, and changes in lake limnology became apparent (e.g. in hypolimnetic oxygen concentrations, transparency, plankton densities, successful restocking of coregonids). This stimulated us to carry out a new study of the planktonic community, with a focus on all the ecological components.

Our work aims to establish the present status (200203) and the potential trend of the ecological quality of Lake Nemi, and compare its status with the conditions reported by a previous study to which we matched our methodology with the previous study in order to facilitate comparison (Avena 1987).

\section{MATERIAL AND METHODS}

Monthly samples of water were collected from February 2002 to January 2003, in order to represent the seasonal evolution of main physico-chemical parameters, and the phytoplanktonic and zooplanktonic assemblages. Due to a technical problem, the chlorophyll- $a$ and phytoplankton sampling started on March 2002. Samples of water were collected from the surface, 5, 10, 15,20 and $25 \mathrm{~m}$ in a central lake station using a 2 litre PVC bottle. Dissolved oxygen concentration, $\mathrm{pH}$ and conductivity were measured in the field on each haul by means of a Winkler's titration kit (Aquamerck Oxygentest $\left.\mathrm{n}^{\circ} 111107\right)$, a field Eutech Instr. $\mathrm{pH}$ meter (EcoScan Ionmeter 5), and a conductivity meter (Cond 6/Tds 6). Temperature profiles and Secchi disc transparency were also measured on each sampling occasion at the same station. A screening of main hydrochemical variables (alkalinity, nitrate, sulphate, chloride, ammonium, calcium, magnesium, sodium, potassium) and trophic variables (total phosphorus and total nitrogen, dissolved reactive phosphorus) was performed by the IRSA laboratories (Istituto di Ricerca Sulle Acque-CNR of Brugherio, Monza) on an aliquot of samples fixed with chloroform and kept at $4{ }^{\circ} \mathrm{C}$ and dark conditions. Only the standard parameters for the trophic evaluation of the lake water were considered in the present work (following OECD 1982; IRSA 1980; EPA 1974), while a further work will be specifically dedicated to the hydrochemical parameters.

Two litres of the water collected were used for chlorophyll- $a$ measurements (performed in the laboratory of Department of Plant Biology, University "La Sapienza" Rome) by means of spectrophotometric method after acetone extraction. Samples of $250 \mathrm{ml}$ were fixed in $4 \%$ formalin and used for quantitative analyses of phytoplankton after sedimentation by means of an inverted microscope. Taxonomic determination was done to the species level.

Quantitative zooplankton samples were collected by means of a plankton net with a $100 \mu \mathrm{m}$ mesh screen and $25 \mathrm{~cm}$ opening diameter. Horizontal tows from the surface, 5, 10, 15 and $20 \mathrm{~m}$ were taken along a horizontal transect of $60 \mathrm{~m}$ ( $1 \mathrm{knot}$ speed for 2 minutes). The samples were fixed in $5 \%$ formalin, and then subsampled in the laboratory ( 3 to 5 subsamples of $1 \mathrm{~cm}^{3}$, depending on the zooplankton abundance in the sample) for identification and counting, by means of an inverted Utermöhl microscope. Only in regard to the zooplanktonic assemblages, comparisons with the previous study were performed by selecting bimonthly sampling dates from the present data set, so as to comply with the corresponding sampling scheme of the previous work.

All data were compared by the non-parametric Wilcoxon test (Wilcoxon 1945).

\section{RESULTS}

\subsection{Physical and chemical variables}

In Lake Nemi, with the exception of climatic unusual seasons, the homoeothermic water period occurs from December to March. In both the study periods $(1982-83 ; 2002-03)$ the annual thermal pattern was similar, but the last sampling date showed an increase of the mean temperature, particularly in the layer of 5-10 m depth (Tab. 2).

Tab. 2. Mean annual temperatures $\left({ }^{\circ} \mathrm{C}\right)$ at each depth in Lake Nemi during the two study period.

\begin{tabular}{lcc}
\hline Depth & $1982-83$ & $2002-2003$ \\
\hline $0 \mathrm{~m}$ & 16.7 & 17.3 \\
$5 \mathrm{~m}$ & 14.6 & 16.4 \\
$10 \mathrm{~m}$ & 10.8 & 12.6 \\
$15 \mathrm{~m}$ & 8.4 & 9.2 \\
$20 \mathrm{~m}$ & 8.1 & 7.8 \\
$25 \mathrm{~m}$ & 8.0 & 7.5 \\
\hline
\end{tabular}

During 1982-83, transparency values ranged from $0.6 \mathrm{~m}$ in June to $5.1 \mathrm{~m}$ in December, with a mean of 1.9 $\mathrm{m}$ in the whole period (Fig. 1). The recent data (200203 ) showed a very different annual evolution with an 


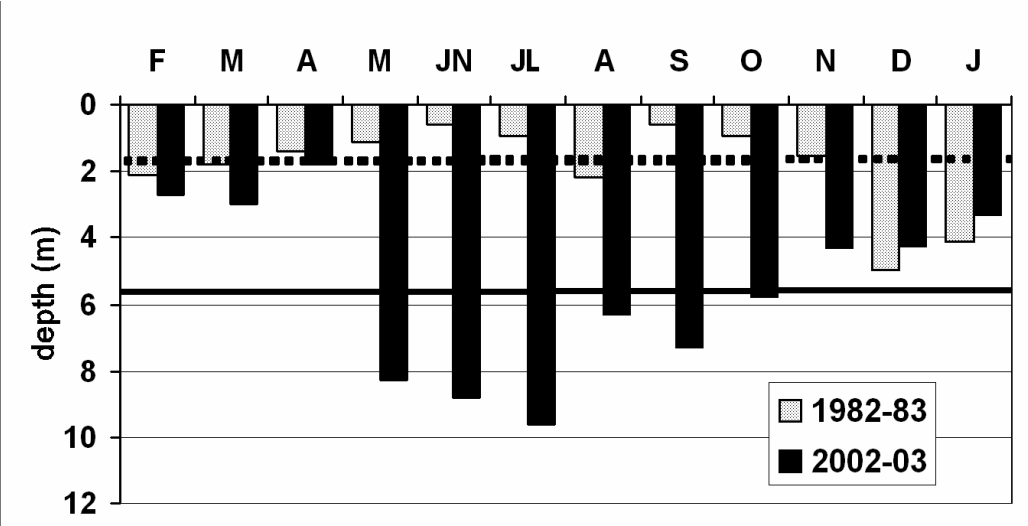

Fig. 1. Comparison among transparency values of the two study periods. Dotted and solid lines represent 1982-83 and 2002-03 annual means, respectively.
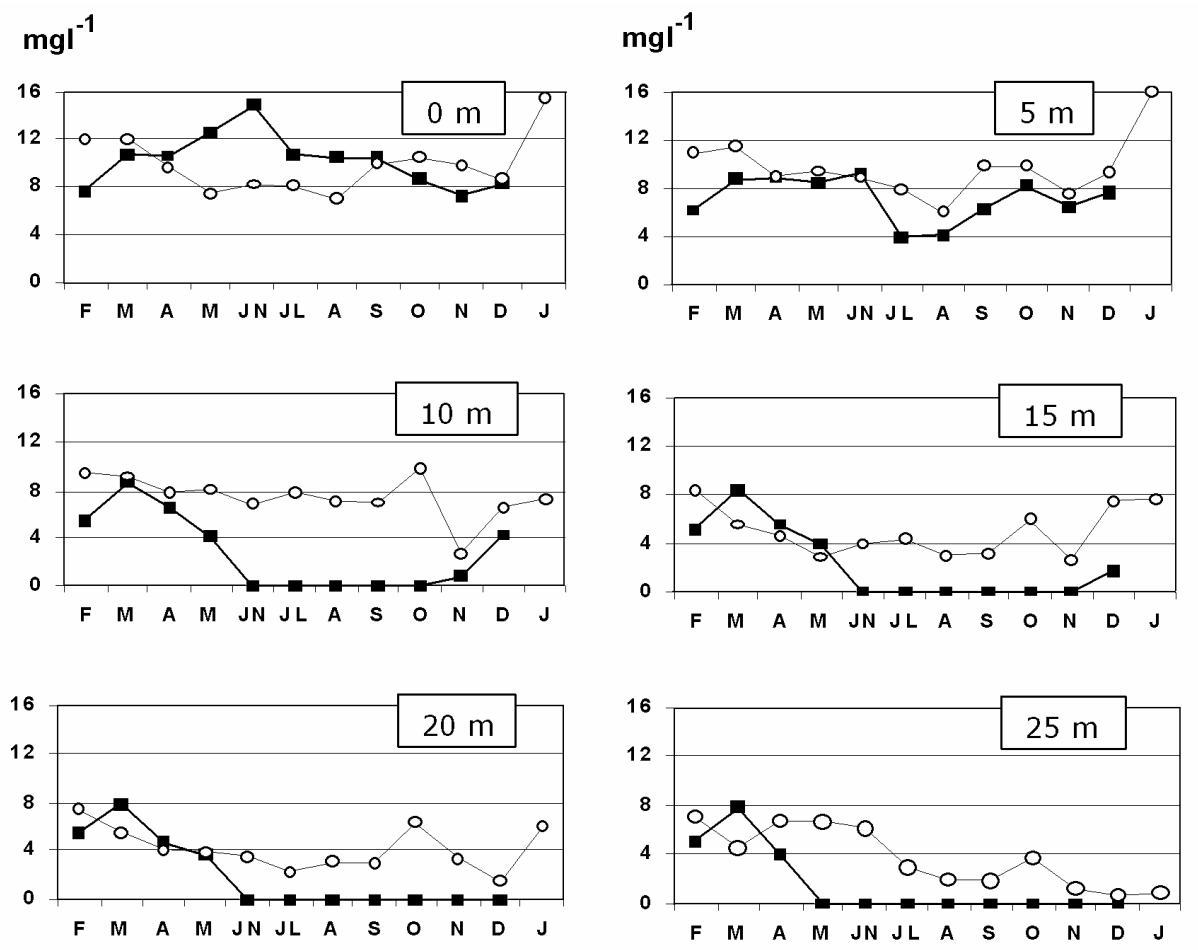

Fig. 2. Comparison between dissolved oxygen concentrations at different depths in the two study periods. Squares and circles represent 1982-83 and 2002-03 samples, respectively.

inversion in the occurrence of the minimum and maximum. High values were measured in late springsummer, with a maximum of $9.6 \mathrm{~m}$ in July, while low values were recorded in winter and early spring, with a minimum of $1.8 \mathrm{~m}$ at the end of April. The annual mean transparency was $5.4 \mathrm{~m}$ (Fig. 1). The difference between mean annual transparency in the two periods was significant at a $p<0.01$ level.

Figure 2 shows the six sampling depths with the relative oxygen concentrations in the two study periods. Large differences were found in the stratification period. In fact, during 1982-83 anoxic conditions were present below $10 \mathrm{~m}$ in the summer and autumn, while during 2002-03 the oxygen never reached zero, in spite of the decreasing concentration in the warm season. In both periods, the oxygen trend was similar at $5 \mathrm{~m}$ and the winter circulation favoured the highest concentration. However, in the surface layer during summer 1982 the values were higher than in winter, as a consequence of the high phytoplankton biovolume (see below).

The concentration of dissolved oxygen in the two periods was significantly different at all depths except the surface $(p<0.01(5 \mathrm{~m}), p<0.005(10 \mathrm{~m})$, and $p$ $<0.05(15,20,25 \mathrm{~m}))$. 

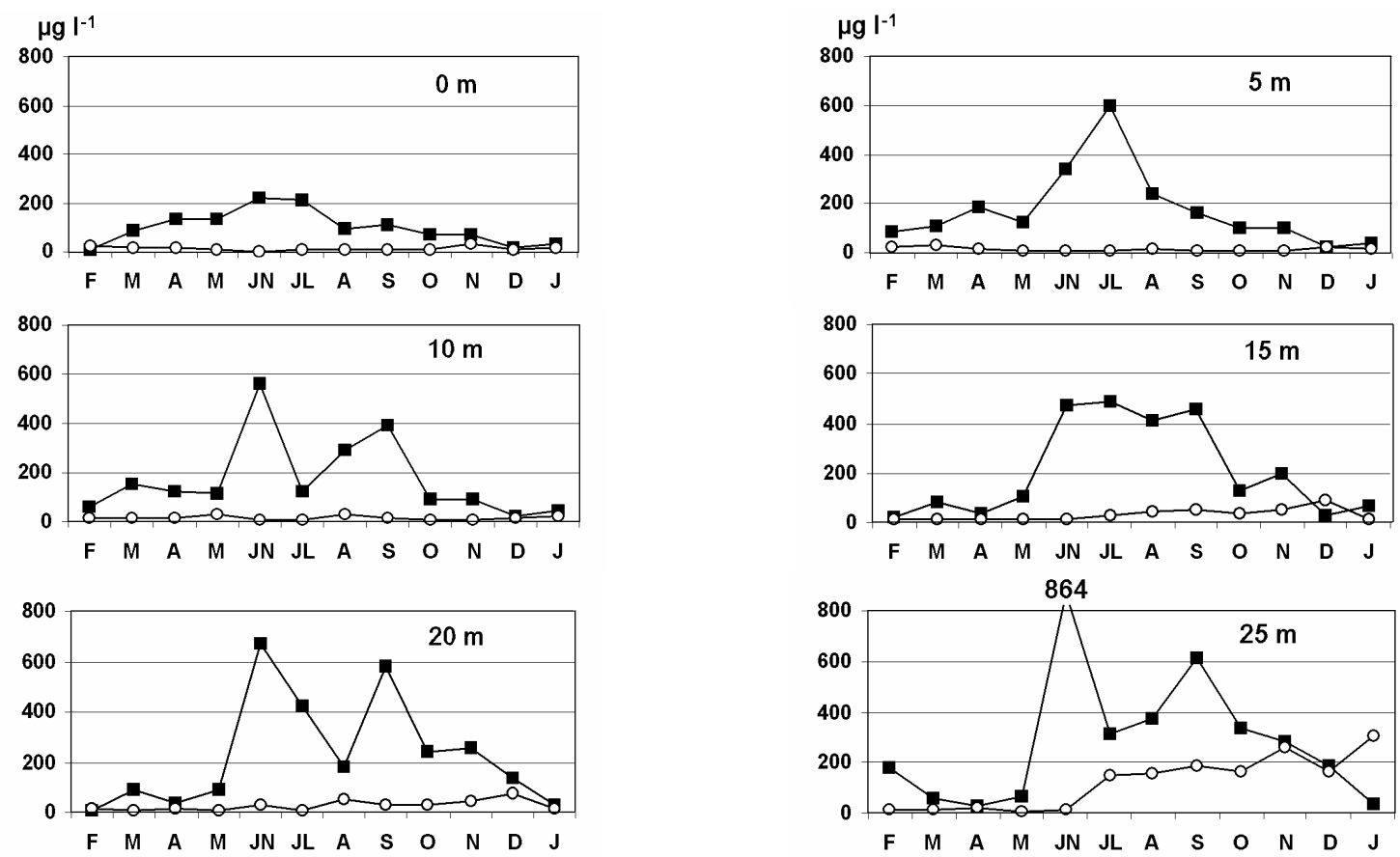

Fig. 3. Comparison between Total P concentrations at different depths in the two study periods. Squares and circles represent $1982-$ 83 and 2002-03 samples, respectively.
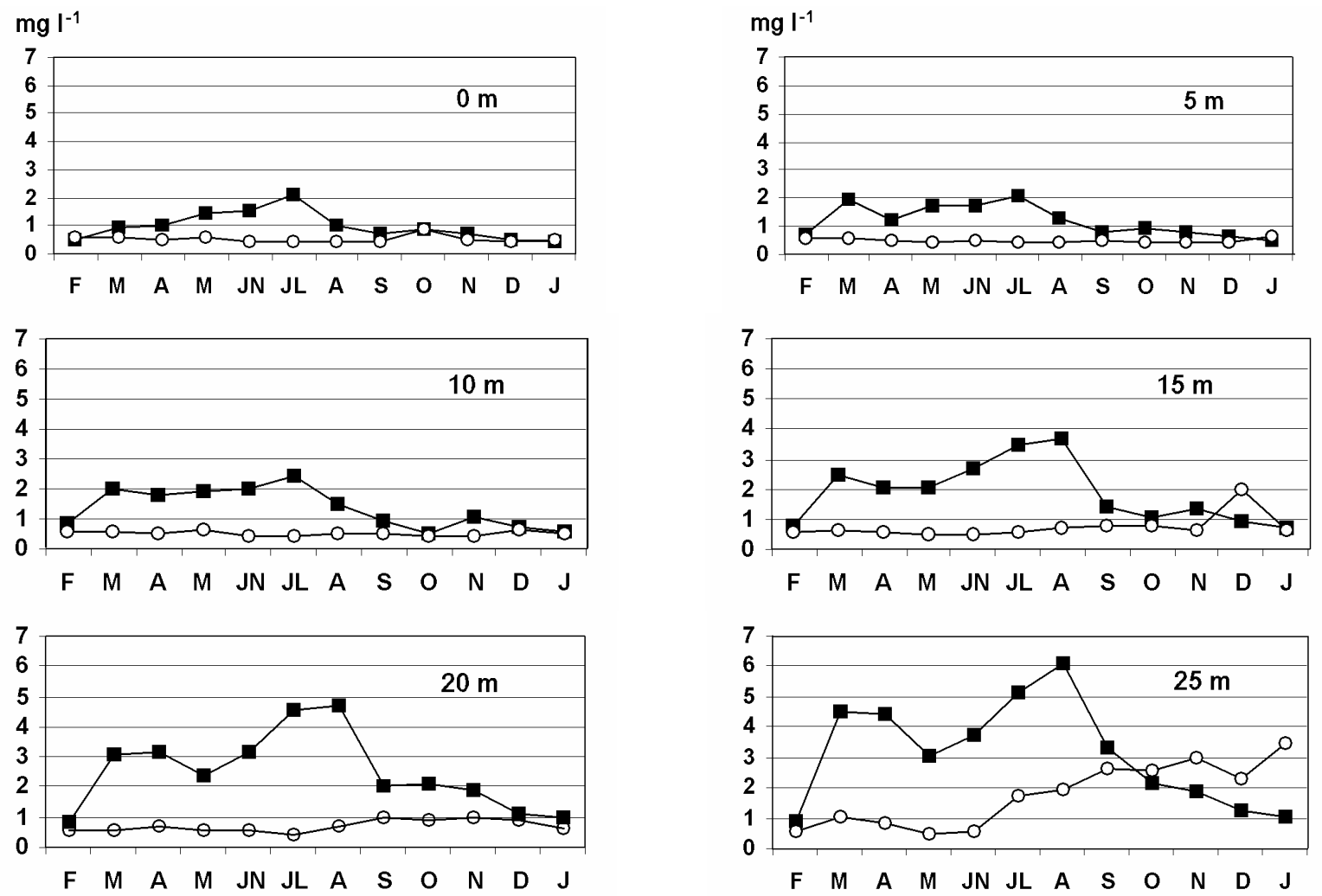

Fig. 4. Comparison between Total $N$ concentrations at different depths in the two study periods. Squares and circles represent $1982-$ 83 and 2002-03 samples, respectively. 

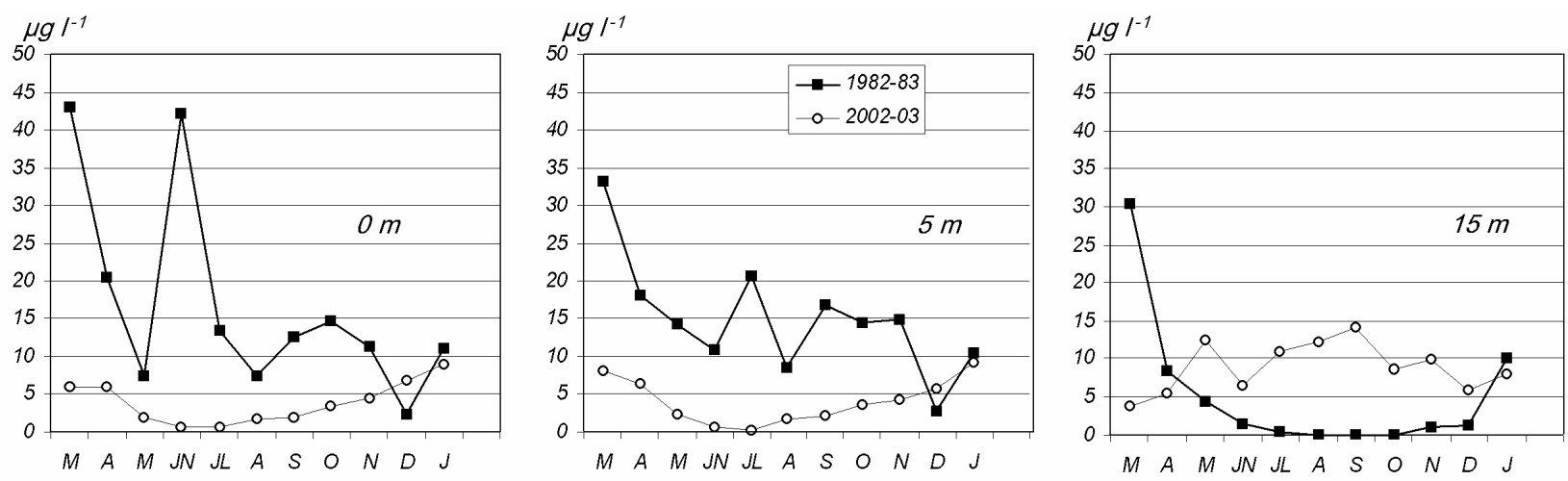

Fig. 5. Chlorophyll- $a$ concentrations at the selected depths of $0 \mathrm{~m}, 5 \mathrm{~m}$ and $15 \mathrm{~m}$ in the two study periods.

The total phosphorus (TP) in 1982-83 (annual range: 4-864 $\mu \mathrm{g}^{-1}$ ) reached very high concentrations in the summer (Fig. 3), especially in the deeper layers (max. $864 \mu \mathrm{g}^{-1}$ in June at $25 \mathrm{~m}$ depth), where there were strong differences between surface and underlaying zones. In the winter TP was lower and there were small differences along the water column. An analogue situation (Fig. 4) was present for total nitrogen (TN). In 1982-83 TN showed an annual range of 0.41-6.09 $\mathrm{mg}^{-}$ ${ }^{1}$ (maximum value $6.09 \mathrm{mg}^{-1}$ in August at $25 \mathrm{~m}$ depth). From March 1982 to August 1982 the values were very high, while in autumn and winter the concentrations were much lower.

After twenty years the values of total phosphorous and total nitrogen along the water column were completely changed. During 2002-03 the TP concentrations

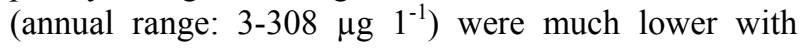
respect to the previous period, especially in the deeper layers. The maximum value was recorded in January at $25 \mathrm{~m}$ depth, with similar values in November and December.

A much lower TN (annual range: 0.42-3.47 $\mathrm{mg} \mathrm{1}^{-1}$ ) was measured in the 2002-03 campaign, and concentrations showed an inverse trend with respect to the previous period: increasing in the autumn and winter with a maximum value in December.

The differences in TP and TN concentrations between the two study periods were significantly different at $p<0.005$ and $p<0.05$, respectively.

\subsection{Chlorophyll-a and phytoplankton seasonal dynamics}

The decrease of the nutrients between the two study periods considerably changed the chlorophyll- $a$ concentration. Three depths were chosen to represent the significant differences for chlorophyll-a: surface, $5 \mathrm{~m}$, $15 \mathrm{~m}$ (Fig. 5). Values from the surface to $5 \mathrm{~m}$ were higher in 1982-83 than in 2002-03 with peaks in spring 1982 (maximum value at surface $42.9 \mu \mathrm{g} 1^{-1}$ in March). The situation was markedly different at $15 \mathrm{~m}$, where the chlorophyll- $a$ concentration reached zero during the stratification period in 1982. In contrast, chlorophyll- $a$ increased at $15 \mathrm{~m}$, and reached a maximum value in September. Differences in chlorophyll- $a$ concentrations between 1982-83 and 2002-03 were significant at the surface and at $5 \mathrm{~m}(p<0.005)$, but not significantly different at $15 \mathrm{~m}$.

The phytoplankton assemblage had 89 taxa during 1982-83 and 100 taxa during 2002-03. The most important difference between the two study periods was in the number of Chlorophyta and Bacillariophyta taxa, and, to a lesser extent, in the number of Cyanobacteria and Euglenophyta taxa (Tab. 3). The other groups remained relatively stable.

Tab. 3. Number of phytoplanktonic taxa (species level) collected in Lake Nemi during the two study period.

\begin{tabular}{lcc}
\hline Taxa & $1982-83$ & $2002-03$ \\
\hline Cyanobacteria & 6 & 11 \\
Chlorophyta & 26 & 50 \\
Dinophyta & 3 & 5 \\
Euglenophyta & 1 & 4 \\
Bacillariophyta & 53 & 30 \\
Total & 89 & 100 \\
\hline
\end{tabular}

Figure 6 shows the phytoplankton biovolume at the same depths as the measured chlorophyll- $a$ concentrations. In 1982-83, the stratification period was characterized by a peak of the phytoplankton biovolume (maximum value: $24 \mathrm{~mm}^{3} 1^{-1}$ in June at surface). The community was mostly composed of Cyanobacteria in the upper layers $(0-5 \mathrm{~m})$ with Aphanizomenon flosaquae v. klebahnii and Oscillatoria limnetica as dominant species, while in deep layer $(15 \mathrm{~m})$ a much lower algal biovolume was measured in the whole period. In 2002-03 phytoplankton biovolume was lower in the zone up to $5 \mathrm{~m}$, especially in the summer. Conversely, the deep part of the lake was characterized by higher algal biovolume (maximum value: $10.1 \mathrm{~mm}^{3} 1^{-1}$ ) and was made up of Cyanobacteria as Limnothrix redekei, Planktothrix rubescens and Merismopedia trolleri. Therefore, the change in the biovolume is in agreement with the change in chlorophyll- $a$ concentrations for 

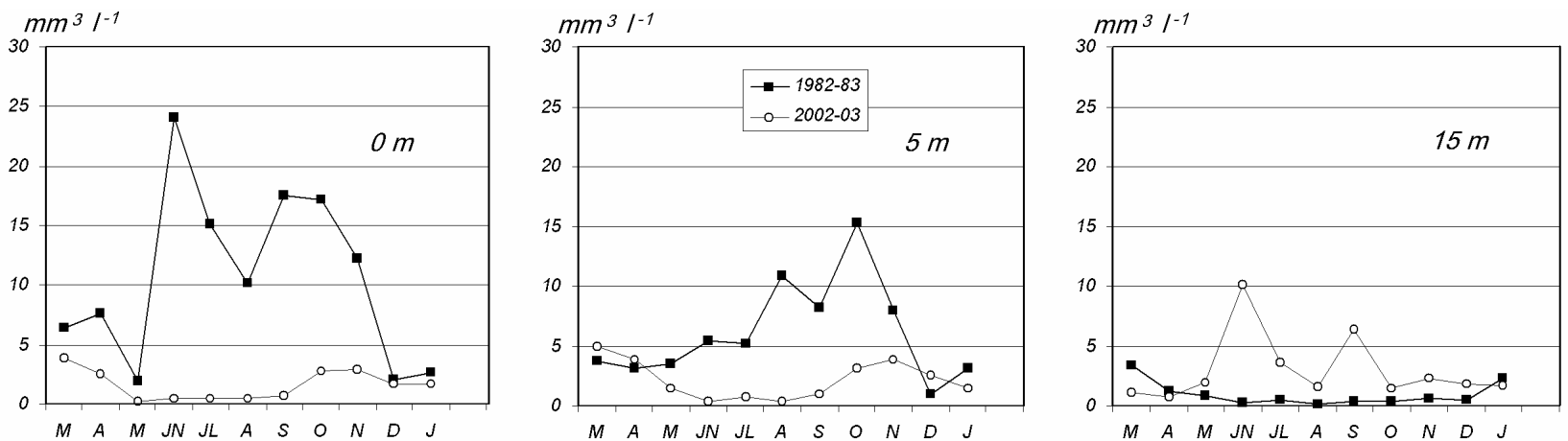

Fig. 6. Phytoplankton biovolumes at the selected depths of $0 \mathrm{~m}, 5 \mathrm{~m}$ and $15 \mathrm{~m}$ in the two study periods.
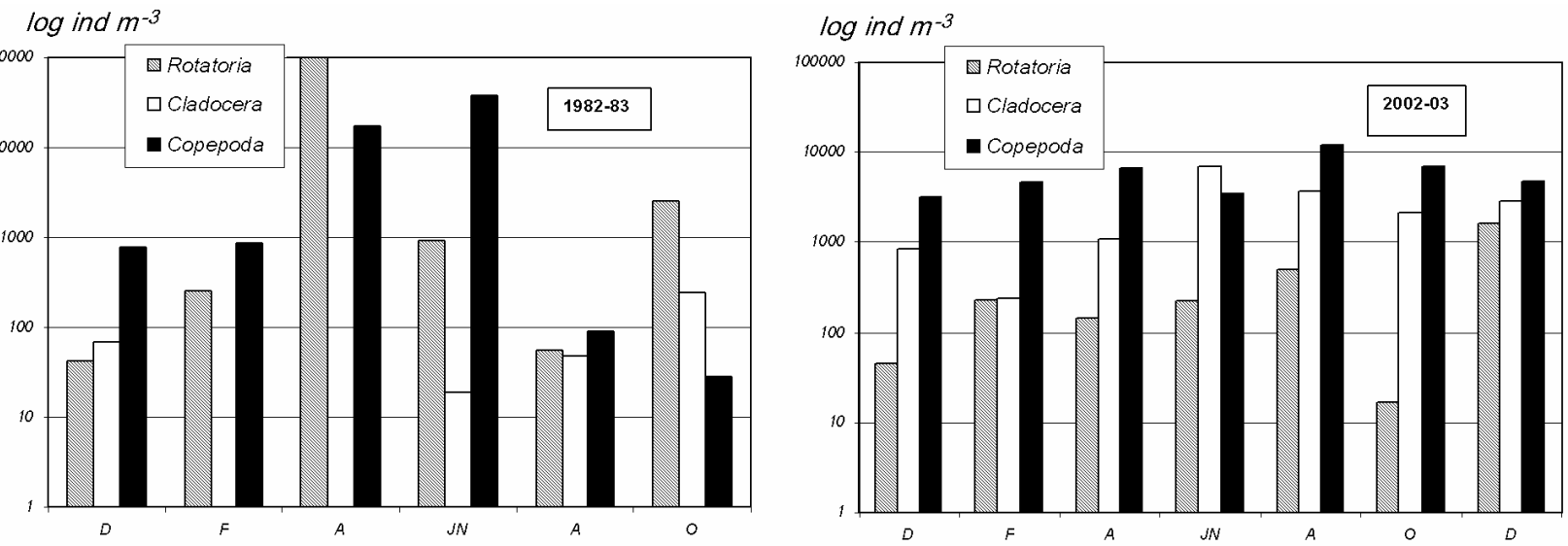

Fig. 7. Density of the main zooplankton groups (sampling depths averaged) in the two study periods.

these two study periods. This change is accompanied by a shift in the dominant species.

\subsection{Zooplankton seasonal dynamic}

The number of zooplankton species was 20 in 1982 and 17 in 2002 (Tab. 4). Apart from some additional taxa found during the first period in some littoral samples (as Chydorus sphaericus and Alona guttata) the pelagic community was similar in the two surveys, was mainly composed of Rotifers, and had many species (8) in common between the two periods.

Tab. 4. Number of zooplanktonic species collected in Lake Nemi during the two study period.

\begin{tabular}{lccc}
\hline & Rotatoria & Cladocera & Copepoda \\
\hline 1982 -Total of species & 12 & 6 & 2 \\
2002 -Total of species & 10 & 4 & 3 \\
$\mathrm{~N}^{\circ}$ of shared species & 8 & 4 & 2 \\
$\mathrm{~N}^{\circ}$ of not shared species & 6 & 2 & 1 \\
\hline
\end{tabular}

Cladoceran and Copepod groups were composed of the same species, with the exclusion of Eucyclops serrulatus, a typically littoral species only found in 2002.
A great difference in the zooplankton quantitative analysis is shown in figure 7. The mean density calculated along the water column was different between the two periods. The zooplankton abundance in 2002 was generally higher than in 1982, but some blooms occurred in spring 1982. In 1982, Cladocerans were usually only present in low abudance for a few months, whereas in 2002, the group reached maximum density in June (6948 ind $\mathrm{m}^{-3}$ ) and occurred in all sampling periods. Daphnia hyalina was occasionally found twenty years ago, but in the more recent survey it occurred on all sampling dates. The life cycle is characterized by a high density up to June 2002 (maximum value: 23,136 ind $\mathrm{m}^{-3}$ at $15 \mathrm{~m}$ in June) but a decrease in abundance in July (60 ind $\mathrm{m}^{-3}$ at $\left.15 \mathrm{~m}\right)$ and low density for the rest of the summer period.

An opposite pattern was observed for rotifers. Rotifer reached considerably higher densities in 1982 (maximum value: 99,489 ind $\mathrm{m}^{-3}$ in April), and remained at extremely low densities in 2002 (maximum value: 1655 ind $\mathrm{m}^{-3}$ in December). In the current study period, copepod density reached a maximum value in August $\left(12,195\right.$ ind $\left.\mathrm{m}^{-3}\right)$ without any bloom. Copepod density in the previous study showed high fluctuations and a sudden increase in density to a maximum value 

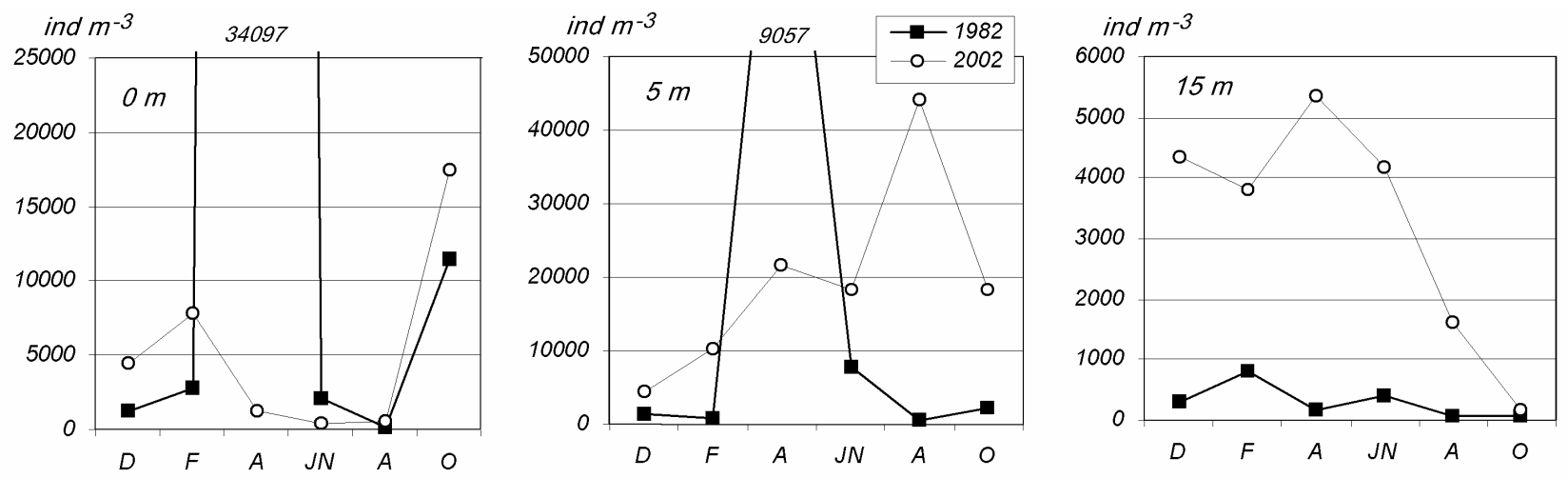

Fig. 8. Density of total zooplankton at the selected depths of $0 \mathrm{~m}, 5 \mathrm{~m}$ and $15 \mathrm{~m}$ in the two study periods.

(37,528 ind $\mathrm{m}^{-3}$ in June). Considering the same depths of phytoplankton, the vertical zooplankton distribution (Fig. 8) revealed a higher density at $5 \mathrm{~m}$ in 2002 and a lower abundance at all depths in 1982 (except for April and June), particularly at $15 \mathrm{~m}$. In 1982 zooplankton were absent in the deeper parts of the lake (below 15 $\mathrm{m}$ ), whereas in 2002, a series of samples carried out at $20 \mathrm{~m}$ revealed a community rich in species.

\section{DISCUSSION AND CONCLUSIONS}

The comparison between the study carried out in 1982-83 and the present data (2002-2003) found some striking changes in Lake Nemi (especially in the physico-chemical parameters) and some variations in biological characteristics, which are more difficult to explain.

The changes that occurred in the values and annual pattern of transparency are to be carefully considered. Not only the mean annual values strongly increased from 1982-83 to 2002-03, but also the annual pattern totally changed throughout the seasons. The maximum values occurred in December during the previous study and in July during 2002-2003. A possible explanation of this striking phenomenon is provided by the trend in total $\mathrm{P}$ concentrations in the two study periods.

Lake Nemi is a phosphorous-limited lake (N/P ratio $>15$, OECD 1982). In the summer period of 1982-83, very high concentrations of total $\mathrm{P}$ were available in the entire water column, and was heavily exploited by phytoplankton in the well lit, surficial zone, producing a negative peak of transparency that occurred throughout the stratification period (6-8 months per year). This is confirmed by high epilimnetic concentrations of chlorophyll- $a$ and a high phytoplankton biovolume in the same upper layer. A possible increase of transparency was restricted to the homoeothermal period, when the short winter daily radiation caused a drop in algal production allowing a relative increase of transparency, a feature resembling dystrophic conditions (Wetzel 2001).

On the contrary, in 2002-2003 the summer epilimnetic concentrations of total $\mathrm{P}$ were the lowest observed during the year (as much as to an oligotrophy level). This prevented massive superficial production by phytoplankton and consequently generated a peak in transparency. However consistent summer production, that did not affect transparency, occurred at deeper layers (i.e., 15 m, see Figs 5, 6). Conversely, the homoeothermal condition (with relative increase of the total $\mathrm{P}$ concentrations) allowed a relevant and well depthdistributed winter-spring production, with chlorophyll- $a$ concentrations and phytoplanktonic biovolumes that extended throughout the water column and was only limited by the daily rate of solar radiation.

Even if not statistically significant, the clear increase (about $2{ }^{\circ} \mathrm{C}$ degrees) of the mean annual temperature at 5-10 m probably represents a symptom of the present thermal trend of this lake, which is affected by chronic decreases in water level (from 32.5 to $27.5 \mathrm{~m}$ depth in 20 years), and progressive warming of the lake (Ambrosetti \& Barbanti 1999) that is strengthened by a particularly hot climatic phase.

In this situation, one would expect a worsening of the oxygenation in the hypolimnetic layers, especially during the stratification period, as a consequence of the inverse relationship between temperature and oxygen concentration, and of the reduction of the lake volume. Conversely, significant differences between the two periods were observed in the oxygen concentration during the year throughout the water column (with the exception of the surface). It is remarkable that anoxia was absent in the hypolimnion during all the thermal stratification of 2002-2003, but the hypolimnion was totally anoxic in 1982-83.

The relevance and stability of this lake's recovery is confirmed by the successful re-stocking of coregonid fishes, which have been repeatedly reintroduced since 1992-93, and currently flourish (Catarci, pers. comm.). It can be inferred that, despite the lake warming, the water level lowering helped an easier, more effective, and probably more frequent water mixing during the homoeothermal phase.

This allowed a good and prolonged oxygenation even in its deepest part. Of course, the nutrient shortage 
and the reduction in primary production, illustrated further on, decisively helped in the process of reoxygenation, allowing a smaller oxygen consumption rate during the critical summer season.

The nutrient content is noticeably different between the two study periods. The significant strong reduction of total phosphorus and total nitrogen annual mean concentrations from the previous study up to now, underlines the effectiveness of the waste water diversion. The above mentioned absence of anoxia in the hypolimnion during the thermal stratification also reduced the release of phosphorus from the sediments (Wetzel 2001), leading to an improvement in the overall water balance, which tends toward nutrient consumption rather than accumulation.

As a consequence of the nutrient reduction, primary production, indicated by the chlorophyll- $a$ concentration, decreased significantly in the epilimnion. Even if not significant at $15 \mathrm{~m}$ depth, the difference between the previous study and 2002-03 become apparent on the graph (Fig. 5), where a substantial production occurred during the year 2002-03 also at this depth. In 1982-83, the extremely low transparency totally cancelled any production at deeper layers in summer-autumn months.

An apparent shift toward a greater diversification of the phytoplankton community (100 taxa) was recorded in the last period, with increasing Chlorophyta and decreasing Bacillariophyta numbers. Cyanobacteria also increased their species richness, and the coccal, nontoxic species Merismopedia trolleri became particularly abundant. Altough Cyanobacteria always maintained the quantitative dominance over the other groups, the overall situation of the phytoplankton composition seems to indicate a more equilibrated community, that is less subject to sudden blooms, more edible to zooplankters, and, moreover, is well distributed in the water column. This last point is supported by the depth distribution of biovolume (Fig. 6) and by the close resemblance with the annual trend of chlorophyll- $a$ (Fig 5). Such a shift in species dominance and depth distribution was previously observed in Lake Michigan (Barbiero et al. 2002), Lake Ontario (Mills et al. 2003), Lake Lucerna (Bürgi \& Stadelmann 2002), Lake Geneva (Anneville et al. 2002), and in Piburger See (Tolotti \& Thies 2002).

In both periods the zooplankton assemblage was dominated by a large number of rotifer species. A substitution in species occurred between the two campaigns but no taxon that might indicate a change in lake trophic conditions was observed in this group. On the contrary, the appearance of a considerable density of the cladoceran Daphnia hyalina in 2002-2003 is symptomatic of a decrease in trophic level, as also reported by Sommer (1994).

The Daphnia cycle is influenced by planktivorous fishes, and $D$. hyalina represents the preferred food for coregonid fishes (Salmaso \& Naselli-Flores 1999; Løvik \& Kjellberg 2003). These predators are probably responsible for the summer decline of Daphnia, which usually occurs at the end of June-July when the young coregonid fishes are released by the fish-farmer from the rearing cages (Catarci, pers. comm.).

On the other side, there seems to be a relationship between the abundance of more edible Cyanobacteria (see above) and the efficient macro-filterfeeder $D$. hyalina. Obviously, as already reported, this situation is supported by the good oxygen levels observed during the stratification period.

Population dynamics of the zooplankton were different in the two sampling periods. In 1982-83 the densities of the groups were low, with the exception of some months which were characterized by real zooplankton blooms. In 2002-2003 there was no sudden increase in density and in all periods the abundances of cladocerans and copepods were elevated, while rotifers showed low densities. Some studies from other lakes (Bodensee, Lake Washington, Lago Maggiore and Lake Mälaren) have shown that temporal changes in trophic state were accompanied by important changes in the zooplankton communities (Einsle 1978; Edmondson \& Litt 1982; Manca \& Ruggiu 1998; Wallin et al. 2000). This is also true of Lake Nemi. Twenty years ago, the high nutrient enrichment, and the consequent abundance of the epilimnetic phytoplankton, supported in some periods a quick and strong increase in zooplankton densities in general, and rotifer microfilterers in particular.

This is typical of hypereutrophic lakes, in which there is a great instability and sudden dominance of some species (above all $r$-strategists) is common, as reported also by Buergi et al. (2003). At present the recovery of trophic state, revealed by the measures of nutrients, oxygen, transparency and chlorophyll- $a$, was also confirmed by the zooplankton seasonal dynamic, which was characterized by a clear equilibrium in the community, no blooms, and a decrease of rotifers (see also Wodajo \& Belay 1984). Altogether this highlights a general improvement of the lake trophic conditions. Moreover, a wider zooplankton spatial distribution along the water column (down to $20 \mathrm{~m}$ depth) was further evidence confirming this recovery hypothesis.

In conclusion, the whole biotic and abiotic factors we considered here showed encouraging evidence for an improvement in lake trophy. Really, this tendency could lead in the future to a more perceptible decrease in the lake trophic level, as the reduction of the nutrient content of the lake becomes more effective. In spite of this, at least two factors (the water level lowering and the climate changes toward higher temperatures), play a constraining role in regards to the oligotrophication of Lake Nemi, as both of them lay out of the controlling capacity of a simple lake managing protocol. Actually, these factors are also dependent on each other, as a further diminution of the lake water volume could cause an obvious, easier warming of the hypolimnion, with a 
consequent reduction of the mean oxygen concentration. The control of lake water level seems then to have priority over all other managing problems, especially if we consider its relevance for all the Latium volcanic lake district (Margaritora et al. 2003).

\section{ACKNOWLEDGMENTS}

The authors wish to thank Mr. C. Catarci for his much valuable help in field sampling operation and for his valiant keeping memory of the Lake Nemi case hystory.

\section{REFERENCES}

Ambrosetti, W. \& L. Barbanti. 1999. Deep water warming in lakes: an indicator of climatic change. J. Limnol., 58: 1-9.

Anneville, O., V. Ginot, J.C. Druart \& N. Angeli. 2002. Longterm study (1974-1998) of seasonal changes in the phytoplankton in Lake Geneva: a multi-table approach. $J$. Plankton Res., 24: 993-1008.

Avena, G.C. (Ed.). 1987. Valutazione della situazione ambientale del Lago di Nemi. Provincia di Roma. Università "La Sapienza", Roma: 247 pp.

Barbiero, R.P., M.L. Tuchman, G.J. Warren \& D.C. Rockwell. 2002. Evidence of recovery from phosphorus enrichment in Lake Michigan. Can. J. Fish. Aquat. Sci., 59: 16391647.

Buergi, H.R., H. Buhrer \& B. Keller. 2003. Long-term changes in functional properties and biodiversity of plankton in Lake Greifensee (Switzerland) in response to phosphorus reduction. Aquat. Ecosyst. Health Manage., 6, (2): 147-158.

Bürgi H. R. \& P. Stadelmann. 2002. Alteration of phytoplankton structure in Lake Lucerne due to trophic conditions. Aquat. Ecosys. Health \& Manage., 5: 45-59.

Chondrogianni, C., D. Ariztegui, P. Guilizzoni \& A. Lami. 1996. Lakes Albano and Nemi (Central Italy): an overview. Mem. Ist. ital. Idrobiol., 55: 17-22.

D'Ancona, U. 1942. Relazione sulle ricerche idrobiologiche e idrografiche compiute nel Lago di Nemi. Int. Revue ges. Hydrobiol., 45: 235-264.

D'Ancona, U. \& L. Volterra-D'Ancona. 1931. Osservazioni preliminari sulle modificazioni idrobiologiche avvenute nel Lago di Nemi durante e in seguito ai lavori di abbassamento eseguiti per il ricupero delle navi romane. Rend. Acc. Naz. Lincei, 13: 217-223.

D'Ancona, U. \& L. Volterra-D'Ancona. 1935. Il plancton del Lago di Nemi prima e dopo l'abbassamento del suo livello. Verh. Internat. Verein Limnol., 7: 497-506.

D'Ancona, U. \& L. Volterra-D'Ancona.1949. Le Dafnie di Nemi in un venticinquennio di osservazioni. La Ricerca Scient., suppl. 19: 3-15.

EPA (U.S. Enviromental Protection Agency). 1974. An approach to a relative trophic index system for classifying lakes and reservoirs. Working Paper n. 24, Corvallis: 44 pp.

Edmondson, W.T \& A.H. Litt. 1982. Daphnia in Lake Washington. Limnol. Oceanogr., 27: 272-293.

Einsle, U. 1978. Qualitative und quantitative Änderungen im Crustaceenplankton des Bodensee Obersees. Arch. Hydrobiol., 82: 300-315.

Hessen, D.O., B.A. Faafeng \& T. Andersen. 1995. Replacement of erbivore zooplankton species along gradients of ecosystem productivity and fish predation pressure. Can. J. Fish. Aquatic. Sci, 52: 733-742.
IRSA (Istituto di Ricerca sulle Acque). 1980. Indagine sulla qualità delle acque lacustri italiane. Quaderni, 43, Milano: $378 \mathrm{pp}$.

Løvik, J.E. \& G. Kjellberg . 2003. Long-term changes of the crustacean zooplankton community in Lake Mjøsa, the largest lake in Norway. J. Limnol., 62: 143-150.

Maldura, C.M. 1939. L'aspetto chimico delle acque del Lago di Nemi prima e dopo il suo parziale svuotamento. Int. Revue ges. Hydrobiol., 28 : 320-339.

Manca, M. \& D. Ruggiu. 1998. Consequences of pelagic foodweb changes during a long-term lake oligotrophication process. Limnol. Oceanogr., 43: 1368-1373.

Manca, M., A.M.,Nocentini, C. A. Belis, P. Comoli \& L. Corbella. 1996. Invertebrate fossil remains as indicators of late Quaternary environmental changes in Latium crater lakes (L. Albano and L. Nemi). Mem. Ist. ital. Idrobiol., 55: 149-176.

Marchesoni , V. 1940. Il fitoplancton del Lago di Nemi prima e dopo l'abbassamento del suo livello (1923-1939). Int. Revue ges. Hydrobiol., $40: 305-345$.

Marchesoni , V. 1949. Un nuovo periodo di osservazioni sul fitoplancton del Lago di Nemi (1939-1948). Hydrobiologia, 1: 333-345.

Margaritora, F.G., M. Bazzanti, O. Ferrara, L. Mastrantuono, M. Seminara \& D. Vagaggini. 2003. Classification of the ecological status of volcanic lakes in Central Italy. $J$. Limnol., 62 (Suppl. 1): 49-59.

Masaferro, J., A. Lami, P. Guilizzoni \& F. Niessen. 1993. Record of changes in the fossil chironomids and other parameters in the volcanic Lake Nemi (Central Italy). Verh. Internat Verein Limnol., 25: 1113-1116.

Mills E.L., J.M. Casselman, R. Dermott, J.D. Fitzsimons, G. Gal, K.T. Holeck, J.A. Hoyle, O.E. Johannsson, B.F. Lantry, J.C. Makarewicz, E.S. Millard, I.F. Munawar, M. Munawar, R. O'Gorman, R.W. Owens, L.G. Rudstam, T. Schaner \& T.J. Stewart. 2003. Lake Ontario: food web dynamics in a changing ecosystem (1970-2000). Can. J. Fish. Aquat. Sci., 60: 471-490.

O.E.C.D. (Organization for Economic Cohoperation and Development). 1982. Eutrophication of waters. Monitoring, assessment and controlling.OECD, Paris: $164 \mathrm{pp}$.

Parise, A. 1960. I Rotiferi del Lago di Nemi dal 1922 al 1943. Arch. Oceanogr. Limnol., 12: 1-95.

Pasquali, A. 1939. Primi dati quantitativi sul plancton di Nemi (1933-1944). Int. revue ges. Hydrobiol., 39: 415-489.

Pielou, E.C. 1969. An introduction to mathematical ecology. Wiley Intersciences, New York: 286 pp.

Salmaso, N. \& L. Naselli- Flores. 1999. Studies on the zooplankton of deep subalpine Lake Garda. J. Limnol., 58 (1): 66-76.

Sommer, U. 1994. Planktologie. Springer-Verlag, Berlin: 274 pp.

Stella, E., L. Ferrero \& F.G. Margaritora. 1978. Alterations of the plankton in a much polluted lake in Central Italy (Latium), the volcanic Lake Nemi. Verh. Internat. Verein Limnol., 20: 1049-1054.

Tolotti, M. \& H. Thies. 2002. Phytoplankton community and limnochemistry of Piburger See (Tyrol, Austria) 28 years after lake restoration. J. Limnol., 61: 77-88.

Volterra, L. 1924. La variabilità delle Dafnie pelagiche nei laghi di Albano e di Nemi. Rend. Acc.Naz.Lincei, s. V, 33: 131-201.

Volterra-D'Ancona, L. 1938. Un nuovo periodo di ricerche sulle dafnie di Nemi (1930-1935). Int. Revue ges. Hydrobiol., 37: 571-608.

Wallin, M., B. Andersson, R. Johnson, H. Kvarnäs, G. Persson, G. Weyhenmeyer \& E. Willén. 2000. Mälaren. Miljötilstånd och utvekling 1965-98. Sveriges Landbruksuniversitet, Uppsala: $94 \mathrm{pp}$.

Wetzel, R.G. 2001. Limnology: Lake and River Ecosystems. $3^{\text {rd }}$ Edition. Academic Press. 1006 pp. 
Wilcoxon, F. 1945. Individual Comparisons by Ranking Methods. Biometrics, 1: 80-83.

Wodajo, K \& A. Belay. 1984. Species composition and seasonal abundance of zooplankton in two Ethiopian Rift

Riceived: August 2004

Accepted: July 2005
Valley lakes - Lakes Abiata and Langano. Tropical zooplankton (Dev. Hydrobiol.), 23: 129-136. 